\title{
Chapter 11 \\ Requirements for the Application \\ of Exemption from Real Estate Acquisition \\ Tax Due to Purpose of Use: Based \\ on the Acquisition of Land Usage \\ for a School Site by an Incorporated \\ Educational Institution
}

\section{Nobuyuki Kobayashi}

\begin{abstract}
When an incorporated educational institution acquires real estate to establish a school, real estate acquisition tax is tax exemption. There are two interpretations of these tax exemption requirements: interpreting that real estate acquisition to establish a school is a requirement for tax exemption and interpreting that the establishment of a school is a requirement for tax exemption requirement. This paper discusses these tax exemption requirements, along with their accreditation standards and limited interpretation.
\end{abstract}

Keywords Real estate acquisition tax $\cdot$ Tax exemption requirements

\subsection{Introduction}

The public land purchased by the Incorporated Educational Institution Moritomo Gakuen (hereinafter referred to as "Gakuen"), which became a topic of social interest ${ }^{1}$ in connection with the appropriateness of sale price of public land and the

\footnotetext{
${ }^{1}$ Regarding this issue, the Director of Gakuen was summoned as a witness at the Budget Committee of the Diet (Dai 193 kai Kokkai Shugiin yosan iinkaigiroku dai 18 go [Minutes No.18 of the Committee of Budget of the House of Representatives in the 193th National Diet] (March 23, 2017), 1-14; Dai 193 kai Kokkai Sangiin yosan iinkai kaigiroku dai 15 go [Minutes No.15 of the Committee of Budget of the House of Councillors in the 193th National Diet] (March 23, 2017), $1-16)$.
}

N. Kobayashi $(\bowtie)$

Kobe University Graduate School of Law, Doctoral Program, Kobe, Japan

e-mail: Kobayashi.nbyk@gmail.com

Y. Asami et al. (eds.), Frontiers of Real Estate Science in Japan, New Frontiers in

Regional Science: Asian Perspectives 29,

https://doi.org/10.1007/978-981-15-8848-8_11 
approval of the establishment of an elementary school, was seized by Osaka Prefecture due to non-payment of real estate acquisition tax. ${ }^{2}$ The tax was subsequently paid. ${ }^{3}$ It was imposed on the acquisition of land that was to be used as an elementary school site, which Gakuen intended to establish because it later withdrew its application for the approval of establishing the school. ${ }^{4}$

Incidentally, real estate acquisition tax is a prefectural tax (Chihō zei hō [Local Tax Act], Art.1, para.1, item.4 and Art.4, para.2 item4. (hereinafter Act)) imposed on the acquisition of real estate (Act, Art.73-2, para.1), and it shall be exempted from the tax provided that certain requirements are fulfilled (Act, Art.73-3-73-7). This includes tax exemption (tax exemption based on Act, Art.74-4, para.1 hereinafter is referred to as "tax exemption due to purpose of use") in the case of real estate acquisition that is made in line with a purpose of use specified in one of the items in Article 73-4 paragraph (1), for example, a school site, grounds of a shrine or temple, or social welfare business (the purposes of use specified in the aforementioned items in that paragraph are hereinafter referred to as "purposes of use for tax exemption") by a party of a public nature such as an Incorporated Educational Institution, religious organization, or social welfare institution.

As for tax exemption for Incorporated Educational Institutions, the paragraph states that when an Incorporated Educational Institution acquires real estate with the purpose of "directly using for child care or education in a school established by an Institute (item (3) of the paragraph)," the acquisition cannot be subject to real estate acquisition tax (main paragraph). This paragraph prescribes tax exemption "in the case of acquisition for use," which, taken literally, implies that in the case that it is "acquired for a specified use," even if later it is not "actually used for childcare or education," the acquisition shall not be imposed on real estate acquisition tax.

However, the prefecture imposed real estate acquisition tax after Gakuen withdrew its application for the approval of the establishment of the elementary school. ${ }^{5}$ The following processes led to this taking place. After an application was made by Gakuen on October 31, 2014, ${ }^{6}$ the Osaka Prefectural Private School Deliberation Committee came to the conclusion on January 27, 2015, that "authorization is given

\footnotetext{
${ }^{2}$ See Asahi Shimbun (morning), May 27, 2017, at 35; Sankei Shimbun (morning), May 27, 2017, at 28; Nihon Keizai Shimbun (evening), May 26, 2017, at 15; Mainichi Shimbun (evening), May 26, 2017, at 9; Yomiuri Shimbun (morning), May 27, 2017, at 34.

${ }^{3}$ See Asahi Shimbun (morning), May 31, 2017, at 30; Sankei Shimbun (morning), May 31, 2017, at 26; Nihon Keizai Shimbun (morning), May 31, 2017, at 39; Mainichi Shimbun (morning), May 31, 2017, at 28; Yomiuri Shimbun (evening), May 30, 2017, at 10.

${ }^{4}$ See Id.

${ }^{5}$ See Id.

${ }^{6}$ See Osakafu Kyōikuchō [Osaka Prefectural Board of Education Office] and Osa-kafu sōmubu [Osaka Prefectural General Affairs Department], Gakkō hōjin moritomo gakuen Mizuho no kuni kinen Shōgakuin setchi ninka shinsei ni kansuru kenshō hōkoku (April 6, 2017) [Inspection report regarding the application to authorize the establishment of the Incorporated Educational Institution Moritomo Gakuen Mizuho no Kuni Kinen Elementary Schoo (April 6, 2017)], 2.
} 
due to the fulfilment of the requirements."7 On June 20, 2016, Gakuen acquired the land for use as an elementary school site, ${ }^{8}$ but on March 10, 2017, Gakuen withdrew its application. ${ }^{9}$ Regarding this withdrawal, the (then) director of the school testified to the Budget Committee of the Diet that this was in line with the opinion of their representative lawyer: "in light of the current situation the private school board is unlikely to accept the application."10 Responding to this, the prefectural governor who made the decision to approve the application recognized that "although there are now serious concerns about falsehoods in the papers submitted to the Committee, no one among the members of the Committee, or from the Private School Department, was aware that such carelessness was exercised in the submitted papers," and "had all the papers been correct and without falsehoods, [the school] could have opened on April 1, 2017."11 The prefecture imposed real estate acquisition tax through this process, but at the time of acquisition of the land, it corresponded to "a case in which real estate is acquired to provide direct education at a school established on that site."

Therefore, based on the real estate acquisition tax imposed on Gakuen, this paper will examine the requirements for the application of tax exemption due to purpose of use. Specifically, first, the meaning of tax exemption due to purpose of use will be defined (Sect. 11.2). Second, we will examine whether the actual fulfillment of the purpose of tax exemption is included among the requirements for the application of tax exemption (Sect. 11.3). Third, the standards for fact-checking the requirements for the application of tax exemption will be examined (Sect. 11.4). Finally, based on a strict interpretation of the requirements for the application of tax exemption due to purpose of use (Sect. 11.5.1), we will consider the appropriateness of applying tax exemption due to purpose of use to Gakuen (Sect. 11.5.2).

\subsection{Meaning of Tax Exemption Due to Purpose of Use}

As shown in the introduction, Article 73-4, paragraph (1), regulates for tax exemption due to purpose of use. Regarding the meaning of this paragraph, Osaka Chihō Saibansho [Osaka Dist. Ct., July 5, 2012, LEX/DB 25483036 (hereinafter Osaka

\footnotetext{
${ }^{7}$ See Osakafu shiritsu gakko shingikai tōshin [written reply of Osaka Prefectural Private Schools Council], No.15 (January 30, 2015), http://www.pref.osaka.lg.jp/attach/5807/00178564/ 270127toshin.pdf [Last accessed December 1, 2017.

${ }^{8}$ See Osakafu supra note 6, at 2.

${ }^{9}$ See Id.

${ }^{10}$ Dai 193 kai Kokkai Shugiin yosan iinkaigiroku dai 18 go [Minutes No.18 of the Committee of Budget of the House of Representatives in the 193rd National Diet] (March 23, 2017), 10 (statement by witness Yasuhiro Kagoike).

${ }^{11}$ Press Conference by Osaka Prefectural Governor, March 29, 2017 (statement by Governor Ichirō Matsui), http://www.pref.osaka.lg.jp/koho/kaiken/20170329.html [Last accessed December 1, 2017].
} 
District Court Judgment)] states, "in such cases, it can be considered that the real estate is to be offered for a purpose of use with an objective that is in the public interest, and, therefore, in terms of policy, this item is interpreted to have the function of exempting the acquired real estate from tax in such cases." (Underlining by author; same hereafter.) Further, the Fukushima Chihō Saibansho [Fukushima Dist. Ct., June 24, 2014, TAINS Z999-8340 (hereinafter Fukushima District Court Judgment)] states that "the acquisition of real estate contributes to the interest of the public in general, and, therefore, by providing tax exemption, the activities of such corporations, among others, are promoted through the alleviation of the economic burden related to such real estate acquisition, which can also be understood as having the political objective of promoting public welfare."

According to the above statements, this paragraph is understood as providing tax exemption through policy from the perspective of public welfare. Furthermore, when comparing to whom this item is applicable and to whom it is not, regardless of whether they may otherwise be equally eligible for the application of real estate acquisition tax, ${ }^{12}$ people who are eligible are considered as being tax exempt. Therefore, this item is understood as prioritizing the provision of favorable treatment toward eligible people over the fairness in the tax application. ${ }^{13}$

\subsection{Do the Requirements for the Application of Tax Exemption Due to Purpose of Use Include the Actual Fulfillment of the Purpose of Tax Exemption?}

As shown in the introduction, Article 73-4, paragraph (1), prescribes tax exemption when land is "acquired for use." Reading this literally, the only requirement in this item is acquisition for a purpose of use that is tax exempt (subjective requirement). While the policy objective of this item was created from the perspective of public welfare (Sect. 11.2), tax exemption would appear to contradict the intention of this item as it would not actually contribute to public welfare unless it was used for tax exemption purposes. Thus, in addition to the subjective requirement, it seems that this item would also include the requirement of actually fulfilling the purpose of tax exemption (objective requirement).

Therefore, this paper will now consider whether the application requirements for this item include only the subjective requirements (Subjective standard) or in

\footnotetext{
${ }^{12}$ Regarding the ability to pay real estate acquisition tax, in Hanrei Hihyō [Case Comments] (Tokyo District Court, July 18, 1964), 16-17, Hiroshi Kaneko said that "the taxpaying ability to pay that acquires real estate is generally viewed with the assumption that the party has the ability to bear other economic burdens, and so taxpaying capacity here is conceptual, rather than realistically supported as in the case of income tax and revenue tax."

${ }^{13}$ See generally Hiroshi Kaneko, Sozeihō [Tax Law] 88-89, Kobundō (22th ed. 2017) (showing an overview of the discourse on the favorable tax measures).
} 
addition to the subjective requirements, the necessity to fulfill the objective requirements (Objective standard).

\subsubsection{Subjectivist Opinions}

The following opinions are viewed as subjectivist.

\section{Masayuki Takasaki’s Opinion}

Immediately prior to the establishment of the current real estate acquisition tax ${ }^{14}$ Masayuki Takasaki, a staff member of Jichi chō Fuken zei ka [Prefectural Tax Policy Division, Local Autonomy Agency] at the time, published his opinion regarding the evaluation criteria for acquisition for use, stating, "It is dependent on either the party having established a purpose of use that is prescribed in the items, or an objective and reliable assumption that it will use the real estate in line with the stated intention soon after acquiring the real estate." 15

\section{Ichiro Ishikawa's Opinion}

In the year after the establishment of the current real estate acquisition tax, regarding the question, "f land acquired ${ }^{16}$ by JR as a site for railroad tracks is neglected because of a change in construction plans, should it not be taxed as something not used for its original business purpose?" Ichiro Ishikawa, a then-staff member of Jichi chō Sōmu bu [General Affairs Department, Local Autonomy Agency], published his opinion that "the decision of whether or not to impose tax is determined by the recognition of the original business purpose at the time of acquisition. Therefore, even if the purpose of use is later altered, it cannot be taxed because the original business purpose at the time of acquisition was exempt from tax."17

\footnotetext{
${ }^{14}$ Current real estate acquisition tax was established in 1954. The law was promulgated on May 13, 1954, but the opinion of Takasaki was published on April 1 of the same year (9 (4), zei, $148(1954))$.

${ }^{15}$ Masayuki Takasaki, Fudōsan shutoku zei, [Real estate acquisition tax], 9 (4) Zei, 50,53 (1954).

${ }^{16}$ At the time of making this statement, Act, Art.73-4, para. 1 regulated that "real estate acquisition tax cannot be levied. . . in the case that Japan Railways. . acquired the real estate for use directly related to the actual business of Japanese National Railways as provided by government ordinance." ${ }^{17}$ Ichirō Ishikawa and Shunichi Kasai, Jitsurei Chihō zei Sōran, [Annual Report of Local Taxation] 187 (Ishikawa), Zeimu Tsushinsha (1955).
} 


\subsubsection{Opinions Understood to be Objectivist}

The following opinions combine both subjectivist and objectivist statements. The underlined parts of each opinion can be read as objectivist, but the intention of those parts is not necessarily clear, and they are here included as opinions that can be understood as being objectivist.

\section{Naohiro Ishida's Opinion}

Naohiro Ishida (staff member of Jichi shō Fuken zei ka [Prefectural Tax Policy Division, Ministry of Home Affairs] during the making this statement) argued that "the recognition of tax exemption purposes of use is provided at the time of acquiring the real estate." Additionally, "such recognition must be made in reference to budget, business plans, minutes, asset lists, contributions, and certificates of relevant agencies as presented by the party acquiring the real estate." Finally, in the case that a purpose of use for tax exemption is presented after the acquisition of the real estate, as long as the real estate has not been used for any other purpose after acquisition, it can be considered that there are no objections to tax exemption, but tax should be imposed immediately if the purpose of use is altered to something that is not tax exempt. Therefore, in such cases, practically, tax is to be temporarily withheld, and when the purpose of use is presented, it must be processed for tax exemption at that time. ${ }^{18}$

\section{Hiroshi Ishijima's Opinion}

Hiroshi Ishijima argued, "recognition for the presentation of a fixed purpose of use is given at the time of the acquisition of real estate by means of budgets, business plans, minutes, asset lists, contributions, and certificates of relevant agencies from the corporation concerned. ... In the case that a purpose of use for tax exemption is presented after the acquisition of the real estate, as long as the real estate has not been used for any other purpose after acquisition, it is tax exempt, but it becomes the subject of taxation if the purpose of use is altered to something that is not tax exempt."19

\footnotetext{
${ }^{18}$ Naohiro Ishida, Chihō zei hō Chikujyō Kaisetsu: Rensai Fudōsan shutoku zei (6) [Local Tax Act point-by-point Interpretation: Real Estate Acquisition Tax (6)], 31 (4) Chihō zei, 138, 142 (1980). ${ }^{19}$ Hiroshi Ishijima, Fudōsan shutoku zei to Kotei shisan zei no Kenkyu [Study of real estate acquisition tax and property tax], 189-90, Shinzansya (2008).
} 


\section{Mitsuaki Usui's Opinion}

Mitsuaki Usui argued, "although one issue is that real estate is rarely used for purpose stated at the time of acquisition, the point in question is how should real estate be processed at the point when its purpose of use becomes definitive after it has already been treated as exempt from tax due to an 'expected use'. In cases where no presentation is made within a timeframe for exercising the right to impose tax, it is possible to do so retroactively." 20

\section{Hironori Urabe's Opinion}

Hironori Urabe argued that rather than meaning "being acquired for use," it has the limited meaning of "directly providing childcare or education." That is, regarding the meaning of "use directly for the purpose of childcare or education," from "the legislative meaning of that regulation... the nature of the taxable item, or its literal interpretation," it is understood to mean a "case in which it is predicted with high probability that it will be used for childcare or education soon after acquisition based on the objectives at the time of acquiring the real estate (land)." ${ }^{21}$ Moreover, as to "whether or not real estate acquisition tax is imposed when securing rights for the acquired land, etc., pertaining to the establishment of a school, etc., by an educational institution, $\ldots$ at the stage of having acquired the real estate and having applied to establish an educational department, etc., it may seem that the real estate in question is neither one thing or the other as it may or may not be used for a purpose that is a target for tax exemption. However, rather than being a completely open-ended situation, it is actually highly likely that the real estate will directly be presented for use in the near future for either childcare or education because (1) it is possible to assume from the application for the establishment of an educational department, etc., that the intention or objective for the acquisition of the concerned real estate is "direct use for childcare or education" by the Incorporated Educational Institution; (2) in practice, it is highly likely that authorization for establishment will be given if the application for establishment of an educational department, etc., is accepted; and (3) if authorization for the establishment of an educational department is received, the real estate will definitely be used "directly for the purpose of childcare or education," and that this is not a blank condition. Instead, it being used for childcare or education directly in the near future is highly probable.

Further, "at the time of acquisition, as it is either 'all or nothing' in connection to... real estate acquisition tax, which corresponds to a tax on a transaction... while it is possible that this can be interpreted to mean that the Incorporated Educational

\footnotetext{
${ }^{20}$ Mitsuaki Usui, Yōsetsu Chihō zei no Shikumi to Hō [Summary: Local Tax Law], 224, Gakuyō Shobō, (2001).

${ }^{21}$ Hironori Urabe, Sozeihō ni okeru Bunri kaishaku to Genkai [Interpretations and Limits in Tax Law], 841, Jigakusha (2013).
} 
Institution has no obligation to pay tax, in a case where authorization is not given to establish an educational department or that the asset is not used for the purpose of direct education due to an existing educational department, based on the intention of the tax exemption regulation, it is logical that the tax office is able to retroactively levy tax at that time."22

\subsubsection{Tax Practice}

Tax is handled in practice in the following way:

"In the case that acquired real estate is presented for tax exemption purposes of use after acquisition, as long as the real estate has not been used for any other purpose after acquisition, there can be no objection to tax exemption. In practice, tax is to be temporarily withheld, and when the purpose of use is presented, it must be processed for tax exemption at that time. However, there is also currently a method whereby temporary tax procedures are imposed, and any tax payments are later returned when the tax is revoked at the point at which the real estate is presented for tax exemption purposes of use." 23

\subsubsection{Judicial Precedents}

In addition to the subjective requirements, in terms of judicial precedents that show the necessity of objective requirements, the Osaka District Court Judgment, Fukushima District Court Judgment, and Sendai Kōtō Saibansho [Sendai High Ct., June 12, 2015, Heise 26 (gyo ko) No.15 (hereinafter Sendai High Court Judgment)] at Fukushima District Court Judgment appeal trial are all subjectivist, as shown below.

\section{Osaka District Court Judgment}

Osaka District Court Judgment can be summarized as follows.

Social welfare corporation $\mathrm{X}$ purchased land (referred hereafter the land in question) with the objective of constructing a child welfare institution. Later, based on the Land Readjustment Act, part of the land in question was reallocated. Therefore, X constructed the child welfare institution on the reallocated land and not on the land in question. In this regard, Osaka Prefecture decided to impose real estate

\footnotetext{
${ }^{22}$ See Id. at 842.

${ }^{23}$ Eisuke Tahara, Fudōsan shutoku zei no yōto hikazei [Exemption from real estate acquisition tax due to purpose of use], 43 (9) Zei, 200, 202 (1988).
} 
acquisition tax on the land in question acquired by $\mathrm{X}$ as it did not fulfill the tax exemption requirements stated in Article 73-4 paragraph (1) item (4-2) (now 4-3) because the child welfare institution was not constructed on the land in question. In objection to this, $\mathrm{X}$ filed a lawsuit in an attempt to revoke this decision.

The necessity of applying the objective requirements was argued in this case. Regarding this point, Osaka Prefecture claimed, "in view of the intention of the tax exemption regulations, the application of tax exemption regulations... requires that the land is actually used for a facility such as a child welfare institution." In this regard, the Osaka District Court argued, "if emphasis is placed on the implementation of policy objectives, rather than determining tax at the time of acquiring the real estate. . in reality, at fixed intervals... it is likely that there would be a system in which exemption from real estate acquisition tax is given when the real estate is actually used in a way that fulfills the policy objectives." "Considering this, legislators... have the space to consider that the judgment of tax exemption was made if it is true that the real estate has been acquired for a purpose of use that is tax exempt, even if the said real estate is not actually used for a tax exempt purpose. Therefore... based on the meaning of the tax exemption regulations... it cannot be derived that the immediate use of the real estate for a tax exempt purpose is a requirement for tax exemption."

Moreover, Osaka Prefecture stated that based on the objective of the policy, there should be a restrictive interpretation of the tax exemption regulations, not an arbitrarily expansive one.

In this regard, the Osaka District Court argued, "certainly, regarding tax exemption regulations based on policy objectives,... from the perspective of ensuring fairness among taxpayers, the interpretation should not be arbitrarily expansive, and, as the defendant has rightly claimed, the interpretation and application should be rigid. However,... the addition to requirements that are not in the wording of the provisions are not a strict interpretation or application, as stated above, and it goes against the principle of taxation without representation as it is considerably injurious to the predictability of the system to taxpayers and legal stability and thus must not be permitted." "In view of the foregoing. . . while it is necessary to have the objective of using the real estate for tax exemption purposes of use (subjective requirement)... it should be understood that the actual use of the real estate for tax exemption purposes (objective requirement) is not a requirement."

\section{Fukushima District Court Judgment}

Fukushima District Court Judgment can be summarized as follows. Regarding the acquisition of a hospital ward by hospital management foundation X, Fukushima Prefecture made the decision to impose tax on the acquisition of the real estate. In response, $\mathrm{X}$ filed a lawsuit seeking this decision to be revoked, claiming that the real estate was tax exempt based on Act, Art. 73-4, para.1, item. 4-7, because the hospital ward was acquired for the purpose of services through which the needy are provided 
with medical care, free of charge, or at low cost, Shakai fukushi hō [Social Welfare Act] Art. 2, para. 3 item. 9.

In the aforementioned case, the Fukushima District Court made the following claim:

“Act, Art. 73-4, para.1 regulates for 'acquisition for use,' and a literal interpretation of this wording would mean that the requirement is for the real estate acquirer to have the objective of using the real estate for one of the items in that paragraph at the time of acquiring the real estate, and it is naturally understood that this is sufficient." "When looking at the tax exemption regulations. . . there is no wording that shows the requirement for actual use for a purpose stated in one of the items in that paragraph." "In view of the fact that real estate acquisition tax is based on "the taxation of a party that is recognized as having the duty to pay tax based on the temporary fact of the acquisition of real estate...' it is obvious and logical to understand that the requirements for the application of tax exemption measures should also be determined on the temporary basis of the acquisition of real estate."

"Therefore...while having the objective of using the real estate for services through which the needy are provided with medical care, free of charge or at low cost is a requirement. . . the actual use of the real estate for services through which the needy are provided with medical care, free of charge or at low cost is not a requirement."

\section{Sendai High Court Judgment}

Sendai High Court Judgment stated that "whether it can be said that the building in question was acquired for use of services through which the needy are provided with medical care, free of charge or at low cost as a social welfare business is decided by the appellant's objective for the use of the building in question at the time of the acquisition of the building in question."

\subsubsection{Analysis}

Should Subjective standard or Objective standard be applied to the requirements for the application of tax exemption due to purpose of use?

Regarding this point, according to Objective standard, the standard is whether the real estate is actually used for tax exemption purposes, which has the advantage over Subjective standard in that it is easier to recognize the validity of tax exemption due to purpose of use. Additionally, if it is not used for a tax exempt purpose, it does not 
contribute to public welfare, so it is more compatible than subjective standard with the intention of tax exemption due to purpose of use. ${ }^{24}$

However, Act, Art. 73-4, para. 1 regulates for "acquisition for use," making it difficult to be understood as including objective requirements in a literal sense. While Act also has a regulation that revokes real estate acquisition tax on the condition that certain circumstances are met within a fixed period of time after acquiring the real estate (for example, housing is newly constructed in line with the fixed requirements for the acquired land (Act, Art.73-24, para.1, item.1), or the transfer of the asset in question from the mortgage holder to the creator of the mortgaged asset (Act, Art.73-27-4, para. 1)), such regulations do not exist with regard to tax exemption due to purpose of use. From this perspective, there can be no recognition for the necessity of meeting objective requirements. This is because if objective requirements are needed, there would obviously be regulations in place limiting the period until the real estate is presented for tax exemption purposes of use. Furthermore, in view of the subjectivist statements of staff member of Jichi chō [Local Autonomy Agency] made immediately before, and in the year after, the creation of the current real estate acquisition tax (Sect. 11.3.1), it can be surmised Jichi chō [Local Autonomy Agency] produced the Act with subjective standard in mind. Furthermore, that assumption can be made from a literal understanding of Act, Art.73-4, para. 1. Based on the foregoing, a Subjective standard should be applied in the requirements for the application of tax exemption due to purpose of use.

\subsection{Standards for Recognizing Subjective Requirements}

As shown in Sect. 11.3.5, the validity of tax exemption due to the purpose of use should be determined based on the existence of subjective requirements. A recognition of the facts in this regard is provided by prefectures (or by courts in legal cases for the withdrawal of the decision to impose tax) as the tax authorities; however, there are two theories regarding the standards for recognizing these facts. One is the standard in which recognition should be given according to the facts at the time of acquisition (referred to hereafter as "standard of time of acquisition"). The other is the standard in which, in addition to the facts at the time of acquisition, recognition is given according to the facts after acquisition (referred to hereafter as "standard of comprehensive consideration"). We will subsequently consider which of these standards should be used.

\footnotetext{
${ }^{24}$ See Fukushima District Court Judgment. (stated that "from the intention of the law, only cases in which the acquired real estate is actually used for services through which the needy are provided with medical care, free of charge or at low cost are consistent with the intention of providing tax exemption.")
} 


\subsubsection{Standard of Time of Acquisition}

Hiroshi Nagashima takes up the standard of time of acquisition, stating, "the circumstances that should be considered to decide the requirements for the application of tax exemption in this case should be limited to the facts at the time of acquiring the real estate, and the facts after acquisition should not be taken into consideration. The reason for this is ability to pay should be determined at that point in time because it is unreasonable to go back to the taxpaying capacity at the time of levying tax (this seems to be a mistake for "time of acquisition"; same below) based on the facts after acquisition, that is, circumstances that are influenced by chance." 25

\subsubsection{Standard of Comprehensive Consideration}

The following judicial precedents all take up the standard of comprehensive consideration.

\section{Osaka District Court Judgment}

Osaka District Court Judgment found the following:

"There are facts regarding the purpose of the acquisition of real estate that are subjective to the acquiring party, and the recognition of such facts can be considered to be challenging, and so, based on the need for a strict examination regarding the application of the regulations for tax exemption in line with the policy objectives... the circumstances after acquisition cannot be denied in their entirety." "As to whether the real estate was acquired for tax exempt purposes of use, in addition to the facts that arise until the time of acquiring the real estate (the contract related to the acquisition of the real estate, the business plans, and the property status of the party that acquired the real estate) it is understood that authorization should be given based on whether the real estate is actually used for tax exemption purposes and various other facts, such as other details and reasons if the real estate is not used for tax exemption purposes." "With this understanding,... it is obvious if the real estate in question is not actually used for tax exemption purposes after acquisition, it is normal to infer from the facts that the purpose of use of the real estate was not tax exemption even at the time the real estate acquisition." "Authorization should always be based on whether the purpose of use, when acquiring the real estate, was for tax exemption, which is determined also with respect to the circumstances after acquisition,... and therefore, the application of tax exemption regulations in this

\footnotetext{
${ }^{25}$ Hiroshi Nagashima, Hanrei Hihyō [Case Comments] (Fukushima District Court, June. 24, 2014), 8 Sozei Soshō, 327, 348 (2015).
} 
case should not be made if the land is not used for tax exemption purposes that unavoidably arise due to a later situation."

\section{Sendai High Court Judgment}

Sendai High Court Judgment found the following:

"The purpose of use should be judged objectively with comprehensive consideration given to both the formal aspects, such as the submission of a notification of the beginning of a social welfare business by the appellant based on the stipulations for articles of endowment and Shakai fukushi ho [Social Welfare Act], and the tangible aspects, such as the actual activities performed by the appellant in the property. Further, the actual activities, etc., carried out by the appellant in the property should be recognized based on objective facts before and after acquiring the property (the objective determination of the purpose of use of the property at the time of acquisition is based on a consideration of objective facts from before and after the acquisition of the property, which does not contradict the fact that the timing of the evaluation standards for the purpose of use is the time of the acquisition of the property)." "Real estate that is acquired to provide services through which the needy are provided with medical care, free of charge or at low cost, which is a purpose that strongly favors public interest, is exempt from tax; therefore, real estate that is also used simultaneously for general medical care will also be exempt from tax. . From this it can be understood that in cases where systems and equipment are in place in the real estate in question for the continuous provision of free or low cost medical services and that such free or low cost medical services are actually being repeatedly conducted on a regular basis, the real estate was acquired for the purpose of services through which the needy are provided with medical care, free of charge or at low cost, because this business that is strongly in public interest is actually being practiced."

\subsubsection{Analysis}

Regarding the standards for authorizing subjective requirements, should either the standard of time of acquisition or the standard of comprehensive consideration be used?

On this point, Hiroshi Nagashima, who takes up the standard of time of acquisition, argued, "It is illogical that the ability to pay tax retroactively is determined by circumstances after acquisition, i.e., by details that are influenced by chance." 26 Certainly, with the understanding that actually using the real estate for tax exemption

${ }^{26} I d$ 
purposes of use is a requirement for the application of tax exemption, the taxpaying capacity is determined by "circumstances that are influenced by chance."

However, based on whether the real estate is actually used for tax exemption purpose and various other facts, such as other details and reasons if the real estate is not used for tax exemption purpose, ${ }^{27}$ if the existence of subjective requirements is recognized, "ability to pay" is not "determined by circumstances that are influenced by chance." Further, "the purpose of the acquisition of real estate involves facts that are subjective to the acquiring party, which are difficult to recognize"; ${ }^{28}$ hence, there is a recognition for the need to take into consideration the circumstances after acquisition. Furthermore, as there are no laws limiting the recognition of subjective requirements, ${ }^{29}$ it is permissible to consider the circumstances after acquisition.

Therefore, the standard of comprehensive consideration should be applied to the standards for recognizing subjective requirements.

\subsection{The Meaning of "Acquisition for Use"}

While all the judicial precedents in Sect. 11.3.4 take up Subjective standard, regarding the interpretation of "acquisition for use," the degree of probability that the real estate will be used for tax exemption purposes at the time of acquisition is not specified. Despite this, Osaka District Court Judgment found the following: (1) "It is obvious if the real estate in question is not used for tax exemption purpose after acquisition; it is normal to infer from the facts that the purpose of use of the real estate was not tax exemption even during the real estate acquisition." Certainly, the interpretation in (1) is valid if the scope of "acquisition for use" is limited to cases in which there is a high probability that the real estate will be used for tax exemption purposes at the time of acquisition. However, if this also includes cases of low probability, the interpretation in (1) is invalid. This is because if in the case of said low probability, real estate is commonly used for a purpose that is not tax exempt after acquisition, which is why the District Court should have clarified the scope. Besides this, Sendai High Court Judgment found the following: (2) "It can be understood that the real estate was acquired for the purpose of services through which the needy are provided with medical care, free of charge, or at low cost. . in the case that free or low cost medical services are actually being repeatedly conducted on a regular basis." 30 In (2), it is understood that the real estate was

\footnotetext{
${ }^{27}$ Osaka District Court Judgment.

${ }^{28} I d$.

${ }^{29}$ See Fukushima District Court Judgment.

${ }^{30}$ See Id. (also found that "it is appropriate to understand that, until the time of acquiring real estate... there should be a recognition of the repeated and frequent provision of free or low cost medical services (in the case of continuing business),... or within a reasonable time after acquiring the real estate, ... there should be a recognition of the repeated and frequent provision of free or low cost medical services (in the case of new business)")
} 
"acquired for use" because it is actually used for a tax exemption purpose. However, there is a contradiction between the Subjective standard taken up by the High Court (Sect. 11.3.4) and (2) (objective standard is consistent with (2)). ${ }^{31}$

The above shows that there are issues with interpreting the aforementioned judicial precedents. Therefore, the interpretation of the meaning of "acquisition for use" will now be considered.

\subsubsection{Analysis}

"Acquisition for use" is a requirement for the application of tax exemption due to purpose of use. How should the regulations for these tax exemption requirements be interpreted? Regarding this, Sendai Kōtō Saibansho, [Sendai High Ct.] January 22, 1975, gyoshu [Administrative Case Reports], Vol. 26, No. 1, p. 3, states that, "while there may be no objection to a narrow and strict interpretation of taxation law and particularly to regulations for tax requisition, regulations for tax exemption requirements in taxation law can be understood as having an exceptional status if regulations for tax requisition are considered to be a general principle, and, substantially, regulations for the requirements for tax exemption are theorized from a financial or politico-economic perspective that is somehow different from the regulations for tax requisition, and, therefore, the demand for the aforementioned narrow and strict interpretation in the applied interpretation of taxation law should be emphasized even further in the applied interpretation of the regulations for tax exemption requirements because they have a so-called obstructive influence in some sense on the concept of the fairness of tax burdens, etc., that the regulations for tax requisition attempt to continually implement.",32

Such an interpretation may also be suitable with regard to the requirements for the application of tax exemption due to purpose of use.

From what perspective, then, should "acquisition for use" be interpreted in a narrow and strict sense? Regarding this point, the following two theories are useful as a reference:

The first is a standard proposed by Takasaki (Sect. 11.3.1). Takasaki states regarding the standard for judging "acquisition for use" that "It is dependent on either the party having established a purpose of use that is prescribed in the items, or an objective and reliable assumption that it will use the real estate in line with the stated intention soon after acquiring the real estate." 33 This standard was advocated

\footnotetext{
${ }^{31}$ supra note 25,346 , Nagashima states that there is a "clear contradiction" in the findings from Fukushima District Court Judgment supra note 30, etc., and the findings shown in Sect. 11.3.4.2.

${ }^{32}$ Saikō Saibansho [Sup. Ct.] July 18, 1978, 24(12) Shōmu geppō 2696, which is the appeal trial ruling for the aforementioned High Court ruling, states that "the original sentence is deemed to be correct because tax exemption regulations should be strictly interpreted."

${ }^{33}$ Takasaki supra note 15, 53.
} 
by a staff member of Jichi chō [Local Autonomy Agency] immediately before the creation of the current real estate acquisition tax in "Showa 29 nendo chiho zeisei kaisetu tokushu [Explanations on the 1954 Local Tax revision]" ${ }^{34}$ which presumably was the standard held by the local government office that produced the law, and therefore, it can be referred to when interpreting "acquisition for use."

Another standard is by Hironori Urabe (Sect. 11.3.2). Urabe states that "the meaning of "use for the purpose of direct care or education" is "a case in which it is predicted that there is a high probability that soon after the acquisition it will be used for nursing or education based on the objectives from the time of real estate (land) acquisition." 35 This standard does not interpret "acquisition for use," but it is consistent with the opinion of Takasaki with regard to the direction of the interpretation. Although both standards include the period up to the use of the real estate for tax exemption purposes and the degree of probability that the real estate will be used for tax exemption purposes, they are still valid. This is because if it is assumed that there will be a lengthy period of time between acquisition and the use of the real estate for a tax exempt purpose, or, if the probability that it will be used for a tax exempt purpose is low, it is unreasonable in terms of fairness among taxpayers that tax exemption should be granted even in such situations despite the fact that there is some small probability that it will be used for a purpose that is not tax exempt.

Additionally, as shown in the standards above, after the acquisition of real estate, if an objective and reliable assumption or a prediction with high probability can be made that the real estate will be used for tax exemption purposes in "the near future" or "soon after," it can be said that the real estate will normally be used for tax exemption purposes after acquisition. Even in such cases, it may not be used for tax exemption purposes. For example, there have been unavoidable situations in which, through no fault of the acquiring party, the acquired real estate cannot be used due to expropriation or land reallocation, for example, or due to the destruction of the acquired real estate in a natural disaster.

Based on the above, "acquisition for use" should be understood as implying acquisition with the intent of using the real estate for tax exemption purposes within a reasonable period of time after acquisition, provided there are no unavoidable circumstances for which the acquiring party is not to blame.

\subsubsection{Suitability of Tax Exemption Due to Purpose of Use in the Case of Gakuen}

In the case that "acquisition for use" is understood as per the meaning provided in Sect. 11.5.1, should tax exemption due to purpose of use be applied in the case of land acquisition by Gakuen? Regarding this point, after making an application for

\footnotetext{
${ }^{34} 9$ (4) Zei, 2 (1954).

${ }^{35}$ Urabe supra note 21,841 .
} 
the authorization to establish an elementary school, Gakuen acquired the land 10 months before the date on which the elementary school was scheduled to open, which, as long as there were no extraordinary problems, is consistent with "acquisition for use."

However, Gakuen later withdrew its application and did not establish the elementary school. The reason being the falsification of the application forms, as recognized by Osaka prefectural governor, and it can be thought that Gakuen would have established an elementary school if the falsehoods had not been present (Sect. 11.1). Further, if it was impossible to make corrections to the application documents, Gakuen did not acquire the real estate with the intention of using it for tax exemption purposes of use within a reasonable time frame after acquisition, provided there were no unavoidable circumstances for which the acquiring party was not to blame (falsified application documents that existed at the time of acquisition is a factor in the recognition of subjective requirements even if it was found only after acquisition); hence, tax exemption due to purpose of use cannot be applied.

\subsection{Conclusion}

This paper has considered the requirements for the application of tax exemption due to purpose of use in connection to real estate acquisition tax. Regarding this point, in practice, tax is either exempted or revoked when real estate is presented for tax exemption purposes (Sect. 11.3.3). However, tax exemption due to purpose of use only has the subjective requirement of acquiring real estate for tax exemption purposes (Sect. 11.3.5), which should be amended if it is understood that the application of tax exemption due to purpose of use also has the objective requirement of actually using the real estate for tax exemption purposes.

The regulation for tax exemption due to purpose of use was established with the objective of achieving things in public interest (Sect. 11.2); therefore, it should be interpreted in a narrow and strict sense from the perspective of maintaining fairness among taxpayers (Sect. 11.5.1). When understood in this way and by applying the standard of comprehensive consideration (Sect. 11.4.3) in which authorization for the subjective requirements should be given based on the circumstances after acquisition along with the circumstances during acquisition, the correct extent of the scope of application of tax exemption due to purpose of use becomes clear, and the difficulty of proving the facts in connection with the subjective requirements is mitigated. 
Open Access This chapter is licensed under the terms of the Creative Commons Attribution 4.0 International License (http://creativecommons.org/licenses/by/4.0/), which permits use, sharing, adaptation, distribution and reproduction in any medium or format, as long as you give appropriate credit to the original author(s) and the source, provide a link to the Creative Commons licence and indicate if changes were made.

The images or other third party material in this chapter are included in the chapter's Creative Commons licence, unless indicated otherwise in a credit line to the material. If material is not included in the chapter's Creative Commons licence and your intended use is not permitted by statutory regulation or exceeds the permitted use, you will need to obtain permission directly from the copyright holder. 